\title{
Migration route, stopping sites, and non-breeding destinations of adult Black-tailed Godwits breeding in southwest Fryslân, The Netherlands
}

\author{
Mo A. Verhoeven ${ }^{1}$ (D) A. H. Jelle Loonstra ${ }^{1}$ (D) Alice D. McBride ${ }^{1} \cdot$ Christiaan Both $^{1}$ (D) Nathan R. Senner ${ }^{1,2} \mathbb{D} \cdot$ \\ Theunis Piersma ${ }^{1,3}$ (D)
}

Received: 4 March 2020 / Revised: 4 July 2020 / Accepted: 1 August 2020 / Published online: 17 August 2020

(c) The Author(s) 2020

\begin{abstract}
In this paper, we extend our understanding of the migration of Black-tailed Godwits (Limosa limosa limosa) by describing: (1) the orientation and geographic locations of individual migratory routes and (2) the spatial distribution of godwits across seasons and years. We accomplish this using satellite-tracking data from 36 adult godwits breeding in the 200-ha Haanmeer polder in The Netherlands, from 2015 to 2018. During both southward and northward migration, godwits used a narrow migratory corridor along which most individuals made stops within a network of sites, especially the Bay of Biscay, France and Doñana, Spain. Most sites were used consistently by the same individuals across years. However, sites in Morocco were used during northward migration by $75 \%$ of individuals, but not revisited by the same individual across years. After southward migration, a small proportion (15\%) of godwits spent the entire non-breeding period north of the Sahara, but most (85\%) crossed the Sahara and spent at least part of the non-breeding season among seven coastal sites in West Africa and one site in the Inner Niger Delta. Although site-use patterns varied among individuals, individuals showed high site fidelity and were consistent in the number of sites they used from year to year. The considerable differences in the spatial distribution of individuals that breed within a kilometre of one another raise questions about the causes and consequences of individual migratory differences. We discuss that full annual cycle tracking of juveniles from birth to adulthood is needed to understand the source of these individual differences. Our results on the spatial distribution of godwits throughout their annual cycle lay an important foundation of information that can be used to help conserve this declining species.
\end{abstract}

Keywords Migratory behaviour $\cdot$ Shorebird $\cdot$ Satellite tracking $\cdot$ Orientation $\cdot$ Routes $\cdot$ Strategies $\cdot$ Black-tailed Godwit $\cdot$ Limosa limosa

Communicated by N. Chernetsov.

Electronic supplementary material The online version of this article (https://doi.org/10.1007/s10336-020-01807-3) contains supplementary material, which is available to authorized users.

Mo A. Verhoeven

m.a.verhoeven@rug.nl

1 Conservation Ecology Group, Groningen Institute for Evolutionary Life Sciences, University of Groningen, P.O. Box 11103, 9700 CC Groningen, The Netherlands

2 Present Address: Department of Biological Sciences, University of South Carolina, 715 Sumter Street, Columbia, SC 29208, USA

3 Department of Coastal Systems, NIOZ Royal Netherlands Institute for Sea Research, Utrecht University, Den Burg, P.O. Box 59, 1790 AB Texel, The Netherlands 


\section{Zusammenfassung \\ Zugroute, Rastplätze und Zielorte außerhalb der Brutzeit bei in Südwest-Friesland (Niederlande) brütenden adulten Uferschnepfen}

Mit dieser Studie erweitern wir unser Verständnis des Zuggeschehens bei Uferschnepfen (Limosa limosa limosa) durch die Beschreibung (1) der Ausrichtung und des geografischen Verlaufs individueller Zugrouten sowie (2) der räumlichen Verteilung der Uferschnepfen über Jahreszeiten und Jahre hinweg. Dies geschieht anhand von Satellitendaten von 36 adulten Uferschnepfen, welche zwischen 2015-2018 im 200 ha umfassenden Haanmeer Polder in den Niederlanden brüteten. Sowohl beim Zug nach Süden als auch nach Norden nutzten die Uferschnepfen einen schmalen Zugkorridor. Die meisten Individuen suchten dabei unterwegs ein Netzwerk aus Rastplätzen auf, besonders die Bucht von Biskaya (Frankreich) und die Donana (Spanien). Die meisten der Rastplätze wurde über die Jahre hinweg regelmäßig von denselben Individuen genutzt. Rastplätze in Marokko wurden allerdings auf dem Zug nach Norden von 75\% der Individuen besucht, über verschiedene Jahre hinweg von diesen Individuen jedoch nicht wieder aufgesucht. Nach dem Zug südwärts verbrachte ein kleiner Teil (15\%) der Uferschnepfen die gesamte Überwinterungszeit nördlich der Sahara, die meisten (85\%) überquerten aber die Sahara und verbrachten zumindest einen Teil der Nichtbrutzeit in sieben Küstenabschnitten in Westafrika sowie in einem Gebiet im inneren Nigerdelta. Trotz individueller Unterschiede in den Nutzungsmustern zeigten die einzelnen Vögel eine hohe Ortstreue und Beständigkeit bezüglich der Anzahl der Rastplätze, welche sie von Jahr zu Jahr nutzten. Die beträchtlichen Unterschiede in der räumlichen Verteilung von Individuen, welche innerhalb von einem Kilometer voneinander brüteten, werfen Fragen über Ursachen und Wirkungen individueller Unterschiede im Zugverhalten auf. Wir weisen darauf hin, dass eine Senderverfolgung über den vollständigen Jahreszyklus der Jungvögel vom Schlüpfen bis zum Altvogel erforderlich ist, um die Ursache dieser individuellen Unterschiede zu ermitteln. Unsere Erkenntnisse zur räumlichen Verteilung der Uferschnepfen im Jahresverlauf liefern eine wichtige Informationsgrundlage, welche dem Schutz dieser zurückgehenden Vogelart dienen kann.

\section{Introduction}

Seasonal migration, the round-trip movement between a breeding location and one or more non-breeding locations, is a strategy that allows organisms to exploit the fitness benefits of being at a breeding location at certain times of the year, while avoiding the costs of staying there continually (Alerstam et al. 2003; Winger et al. 2019). Seasonal migration occurs in numerous shapes and forms, and varies among species and populations, as well as among and within individuals (Newton 2008). Consider, for example, the apparent dichotomy between obligate and facultative migrants; in some species, all individuals migrate each year (obligate), while in other species, only some individuals migrate in some years (facultative; Newton 2008). Such differences are thought to be largely context specific, reflecting differences in the ecological circumstances experienced by species, populations, or individuals (Alerstam et al. 2003).

The fact that populations differ in migratory behaviour is fascinating from a life-history perspective-but also essential to the conservation of migratory species. It means that to conserve a population, researchers must first learn about the migratory routes, stopover sites, and non-breeding locations on which the population relies (Piersma and Baker 2000; Webster and Marra 2005). This knowledge about a population's distribution is necessary to develop, in turn, an ecological understanding of why the population relies on certain geographic areas but not others, and what effect the conditions at such sites might have on the population's demography (Alves et al. 2013; Rakhimberdiev et al. 2018). Finally, this ecological understanding can be used to further conservation efforts directly - for example, by assessing which sites are of the highest priority to conserve, what can be done to improve conditions at those sites in the event of degradation, and whether there are similar alternative sites available elsewhere (Reynolds et al. 2017; Chan et al. 2019a; Rushing et al. 2020).

It is also becoming increasingly clear that populations vary with respect to the similarity or dissimilarity among the migratory routines of individuals (Sergio et al. 2014; Lok et al. 2015; Eichhorn et al. 2017; Ruthrauff et al. 2019). Determining that individuals have different migratory routines and testing whether the causes of such individual variation are the same among populations are exciting avenues of research in their own right (Mellone et al. 2012; Trierweiler et al. 2014). However, acquiring this knowledge is also important for effective conservation, because it is intimately connected to both the vulnerabilities and potential flexibility of a given population (Gill et al. 2019; Senner et al. 2020).

Whether all individuals rely on the same routine, or whether they have multiple routines, could mean a population is more or less vulnerable to changing conditions, such as the degradation or loss of certain sites (Piersma et al. 2016; Studds et al. 2017). Understanding the causes of variation in migratory routine among individuals-i.e., whether a population possesses the plasticity to develop multiple routines, or whether it faces environmental or organismal constraints such as a lack of sites, lack of genetic variation, or 
lack of suitable information (Winkler et al. 2014) -is potentially even more important (Senner et al. 2020). Gaining such an understanding will help to identify the mechanism(s) by which a population can adjust to altered surroundings and thus inform effective conservation measures (Piersma 2011; Gill et al. 2019).

Our goal in this study is to describe the spatial distribution of Continental Black-tailed Godwits (Limosa limosa limosa, hereafter "godwits") throughout their annual cycle and to assess whether individuals have consistently different migratory routes. This information will provide a foundation on which the management and conservation of godwits can be based and contribute to the understanding of the ecological basis of intraspecific variation in migratory routines. Godwits are a ground-nesting, relatively long-lived shorebird that breed across Europe (Gill et al. 2007). Currently, we know that godwits breeding in The Netherlands either spend the entire non-breeding period in the Mediterranean or cross the Sahara to spend at least part of the non-breeding period in the Sahel zone of West Africa (Hooijmeijer et al. 2013; Kentie et al. 2017; Verhoeven et al. 2019), where the non-breeding period lasts from the termination of southward migration until the departure on northward migration. Individual adults are consistent in whether they cross the Sahara at all, and although among-individual differences in the timing of the Sahara crossings are large, individual godwits are relatively consistent in their timing of this crossing (Verhoeven et al. 2019). Adult godwits are also highly consistent in their use of "stopping" sites (a term used to collectively refer to stopover and staging sites-see "Methods"; Warnock 2010; Chan et al. 2019b) on the Iberian Peninsula during northward migration (Verhoeven et al. 2018), but nonetheless may vary the number of stops they make over the course of their migration between years (Senner et al. 2019).

The picture that emerges from past godwit tracking efforts is an interplay between individual consistency and environmental contingency: individuals have a routine, but they may be forced to adjust it in response to the ecological conditions they encounter (Senner et al. 2015, 2019). In this context, it is necessary to map as fully as possible the entire network of stopping sites used by godwits, to understand the full range of alternatives that may (or may not) be available to an individual given their routine and the conditions they encounter en route (sensu Taylor and Norris 2007). Furthermore, this information will aid in the maintenance and restoration of stopping and non-breeding sites-a goal which has been classified as "high priority" by the International Single Species Action Plan for the Conservation of the Black-tailed Godwit (Jensen et al. 2008). Such information can only be gained through the repeated tracking of individuals, which remains difficult because of both the cost and limitations of tracking technologies (McKinnon and Love 2018). In addition, we lack even basic information about the flight orientation of migrating godwits. Knowing the direction an individual flies could help shed light on the degree to which deviations from its routine may be in response to conditions on the ground (e.g., fuel reserves) or encountered mid-flight (e.g., wind).

To extend our understanding of the natural variation of godwit migratory routes, we collected tracking data from 2015 to 2018 from satellite tags deployed on 36 individual adult godwits breeding within a kilometre of each other in The Netherlands. Because we tracked 19 individuals on multiple southward migrations and 12 individuals on multiple northward migrations, we were able to quantify the spatial consistency of individuals during their migratory and stationary periods, as well as their flight orientation during each segment of their migration. These results provide a foundation for future research into inter- and intraspecific variation in migratory patterns by extending our knowledge of the individual routines of godwits and offering one of the most complete overviews of migration yet assembled for any shorebird species.

\section{Methods}

\section{Deploying satellite tags}

During the breeding seasons of 2015-2017, we used walkin and automated drop-cages to capture adult godwits on their nests in the 220-ha Haanmeer polder, The Netherlands $\left(52.9226^{\circ} \mathrm{N}, 5.4336^{\circ} \mathrm{E}\right)$. After catching an adult, we marked it with a unique colour-ring combination and measured its tarsus-toe (without nail) and bill length (exposed culmen), and weighed it to the nearest gram. In 2015 and 2016, we deployed 32 solar-powered PTT-100s of $9.5 \mathrm{~g}$ from Microwave Technology Inc. using a leg-loop harness of 2-mm Dyneema rope (Lankhorst Ropes, Sneek, The Netherlands). Because of the substantial weight of this attachment $(\sim 10.5 \mathrm{~g})$, we deployed these transmitters only on birds that we classified as "large". As a rule of thumb, we selected birds with at least one, but usually two of the following characteristics: tarsus-toe length $>120 \mathrm{~mm}$, bill length $>100 \mathrm{~mm}$ and body mass $>300 \mathrm{~g}$ (see Schroeder et al. 2008 for the range of these measures in godwits). In 2017, we deployed four 5-g solar-powered PTT-100s from Microwave Technology Inc., again using a leg-loop harness made of 2-mm Dyneema rope. The total weight of this attachment was considerably lower ( $\sim 6 \mathrm{~g})$, so we deployed these tags on godwits without selecting for size.

Based on a combination of morphological characteristics ( $n=10$ individuals, see Schroeder et al. 2008) and molecular sexing ( $n=26$ individuals), we determined that our sample of transmitter-carrying birds consisted of 34 females and 2 males. Although we mostly tracked 
females, we believe our results are representative of the entire adult population. The small number of satellite tracks obtained for males (Senner et al. 2019, this study) and the much larger sample of geolocator tracks of males (Hooijmeijer et al. 2013; Verhoeven et al. 2019) indicate that there are no sex-specific differences in the largescale patterns of movement in godwits. This is further supported by more recent satellite-tracking efforts that include more males (T. Piersma, R. Howison, J. Hooijmeijer, A.H.J. Loonstra and M.A. Verhoeven unpubl. data). In 2015 and 2016, the loading factor of the transmitters was $3.4 \% \pm 0.2$ (range $3.0-4.0 \%$ ) of a female's body mass at capture; in 2017 , the loading factor was $1.9 \%$ for each of the two females and $2.2 \%$ for each of the two males.

\section{Tracking data}

Thirty-four of the 36 transmitters were programmed to turn on for $8 \mathrm{~h}$ and turn off for $24 \mathrm{~h}$. One transmitter was programmed to turn on for $8 \mathrm{~h}$ and off for $25 \mathrm{~h}$, and one was programmed to turn on for $10 \mathrm{~h}$ and off for $48 \mathrm{~h}$; these two transmitters had been deployed previously in two other tracking studies that used these different duty cycles. The birds outfitted with a 9.5-g transmitter were considered dead when their transmitter's built-in activity sensor remained constant. The 5-g transmitters did not have such an activity sensor, but they did have a temperature sensor; we considered these birds dead when the measured temperature dropped and began following a day-night rhythm. For both the 9.5-g and 5-g transmitters, we considered a bird to be dead when its transmitter suddenly stopped transmitting and never turned on again; we feel that this is reasonable, as we never subsequently observed any of these 36 individuals alive during our resighting efforts of marked birds at the breeding grounds, stopping sites, or non-breeding sites (Verhoeven et al. 2018; Loonstra et al. 2019a).

All tracking data were extracted from the CLS tracking system (http://www.argos-system.org) and stored at Movebank (http://www.movebank.org). In Movebank, we selected all data up to 1 October 2018 and used the "Best Hybrid" Douglas Argos-Filter Algorithm (Douglas et al. 2012) to remove implausible locations by setting the threshold for maximum movement rate to $120 \mathrm{~km} \mathrm{~h}^{-1}$. This resulted in an average of $3.00 \pm 0.24$ locations per individual duty cycle. On the breeding grounds, we have been able to simultaneously compare the locations received through the CLS tracking system with actual observations of these godwits. The error rarely exceeds $5 \mathrm{~km}$ and, therefore, is unlikely to affect the large-scale patterns of movement presented here (M.A. Verhoeven and A.H.J Loonstra pers. obs.).

\section{Annotating and plotting migratory tracks}

We plotted every individual's tracking data in Google Earth and, from the resulting tracks, determined the spatial organisation of each individual's annual cycle. To do this, we divided the individual's locations into four groups: (1) at the breeding grounds, (2) in flight, (3) at stopping sites during migration, and (4) at non-breeding sites during the period between termination of southward migration and departure on northward migration. We considered all points north of $52^{\circ} \mathrm{N}$ to be on the breeding grounds. All points that were not in the same location, but rather made up a route toward a new location, were considered to be in flight. Points at the same location during migration were considered to be at stopping sites and points after the termination of southward migration were considered to be at non-breeding sites. The termination of southward migration occurred either when an individual first arrived at a site in West Africa (for those individuals that crossed the Sahara) or when an individual arrived at its most southern site (for those individuals that spent their non-breeding period north of the Sahara, i.e., on the west coast of Portugal, or in Doñana or Morocco).

Warnock (2010) states that all sites used by birds to stop during migration are stopover sites, but that any stopover sites used for longer periods to fuel for longer flights should be further classified as staging sites. Because godwits stop at certain sites for both long and short periods of time (Table 1), we cannot differentiate between stopover and staging sites. For this reason, we refer to all sites used during migration as "stopping" sites (following Chan et al. 2019b). We used the annotated data to combine and plot all of our individual tracking data, and created two plots that show: (1) in-flight locations and stopping sites during southward migration, plus the non-breeding sites (Fig. 1a), and (2) inflight locations and stopping sites during northward migration (Fig. 1b). These maps were made following the example of Vansteelant et al. (2017); we downloaded a relief map from Natural Earth (http://www.naturalearthdata.com) and masked the seas by overlaying a high-resolution shoreline map obtained from the National Center for Environmental Information (http://www.ngdc.noaa.gov/mgg/shorelines). We then plotted the locations on the resulting map using "ggplot2" in R (Wickham 2016; R Core Team 2018).

\section{Analysis}

We quantified three different aspects of the variation in migratory routes: (1) variation in orientation, (2) longitudinal distribution of tracks at each latitudinal boundary, and (3) variation in the use of stopping and non-breeding sites. Since our goal was to make comparisons between different routes, and because godwits do not migrate in a straight line (Senner et al. 2018; Loonstra et al. 2019b), we did not 
Table 1 Summary of passage dates and lengths of stay for every stopping site used on migration north of the Sahara $\left(>28^{\circ} \mathrm{N}\right)$

\begin{tabular}{lllll}
\hline Site & Direction & Individuals & Passage dates & Length of stay (days) \\
\hline 1. Northwest Europe & $\mathrm{S}$ & 6 & 12 Jun-12 Aug & $4.5 \pm 3.4(1-10)$ \\
2. Bay of Biscay, France & $\mathrm{N}$ & 11 & 11 Mar-6 Apr & $1.9 \pm 1.3(1-4)$ \\
& $\mathrm{S}$ & 16 & 2 Jun-15 Aug & $8.0 \pm 9.3(1-41)$ \\
3. Côte du Soleil, France & $\mathrm{N}$ & 20 & 27 Feb-8 Apr & $5.8 \pm 4.5(1-16)$ \\
& $\mathrm{S}$ & 1 & 5 Jun-11 Jun & 6 \\
4. North of the Pyrenees, France & $\mathrm{N}$ & - & - & - \\
5. Province of Léon, Spain & $\mathrm{S}$ & - & - & - \\
& $\mathrm{N}$ & 1 & 1 April-2 April & 1 \\
6. Balearic coast, Spain & $\mathrm{S}$ & - & - & - \\
& $\mathrm{N}$ & 1 & 23 Mar-24 Mar & 1 \\
7. Extremadura Region, Spain & $\mathrm{S}$ & 2 & 22 Jun-12 Aug & $8.5 \pm 6.8(2-18)$ \\
& $\mathrm{N}$ & 4 & 12 Jan-27 Mar & $17.3 \pm 13.9(1-45)$ \\
8. West coast of Portugal & $\mathrm{S}$ & 5 & 24 Jun-31 Jul & $2.5 \pm 3.7(1-10)$ \\
& $\mathrm{N}$ & 6 & 31 Jan-27 Mar & $13.0 \pm 13.2(4-45)$ \\
9. Doñana, Spain & $\mathrm{S}$ & 10 & 16 Jun-10 April & $80.6 \pm 113.0(1-277)$ \\
& $\mathrm{N}$ & 14 & 16 Jun-10 April & $55.6 \pm 37.8(13-149)$ \\
10. Morocco & $\mathrm{S}$ & 28 & 9 Jun-29 Mar & $37.9 \pm 59.2(1-281)$ \\
& $\mathrm{N}$ & 17 & 9 Jun-29 Mar & $37.9 \pm 41.2(3-187)$ \\
& $\mathrm{S}$ & 7 & 19 Jun-13 Oct & $20.3 \pm 37.5(1-112)$ \\
\hline
\end{tabular}

Names and numbers correspond to those used in Fig. 1. For sites where godwits were present during the entire non-breeding period, the passage dates are given in bold assume a straight migration during the programmed "off" cycle of the transmitters (which is often done in tracking studies). Rather, in our analyses we used only those routes that were actually observed during the "on" cycle of the transmitters.

\section{In-flight orientation and distribution}

We quantified an individual's orientation during south- and northward migration by calculating its longitudinal (i.e., east-west) movement, measured in kilometres, between latitudinal boundaries (Fig. 2). Latitudinal boundaries were spaced $1^{\circ}$ of latitude apart along the migratory route (from $52^{\circ} \mathrm{N}$ to $18^{\circ} \mathrm{N}$, Fig. 3a). To calculate longitudinal movement, an individual's tag had to have been transmitting live data when crossing at least two consecutive latitudinal boundaries (Fig. 2). We also quantified the longitudinal distribution of tracks at each latitudinal boundary. To account for the fact that degrees of longitude differ in width at different latitudes, we expressed the longitudinal distribution as the number of kilometres between individual tracks, measured from west to east, at each latitudinal boundary (Fig. 2). The most westerly track at each latitudinal boundary was considered to be at zero; since godwits do not migrate directly north to south, this allowed us to compare the longitudinal distributions with each other and examine the spatial distributions of tracks along the entire migratory corridor
(Fig. 3b). To calculate the longitudinal distribution, more than one tag had to have been transmitting live data at a given latitudinal boundary (Fig. 2). It was more common to have multiple tags transmitting at a single latitudinal boundary than to have a single tag transmitting for two consecutive latitudinal boundaries, but both of these circumstances occurred relatively frequently in our dataset (see dots in Fig. 3 for sample sizes). When possible, we also calculated the difference between the routes of the same individual in different years for both measurements. However, this sample size is small because it requires a tag to have been transmitting live data at the same place in different years.

To calculate the distances between points, we used the function "distHaversine" in the R package "geosphere" (Hijmans 2017). We then used Levene's test, which is part of the R package "car" (Fox and Weisberg 2019), to compare the variances of the longitudinal movements and longitudinal distributions across latitudes. Only in the case of longitudinal distribution on northward migration did this Levene's test indicate that the variances were not homogeneous across latitudes. There are no post hoc tests, such as pairwise comparisons, to further assess between which specific latitudes the variances are not equal to each other. For this reason, we relied on visually inspecting Figs. $1 \mathrm{~b}$ and $3 \mathrm{~b}$ and directly comparing variances between latitudes; though this is by no means a formal statistical test, it could nonetheless be informative. However, we 


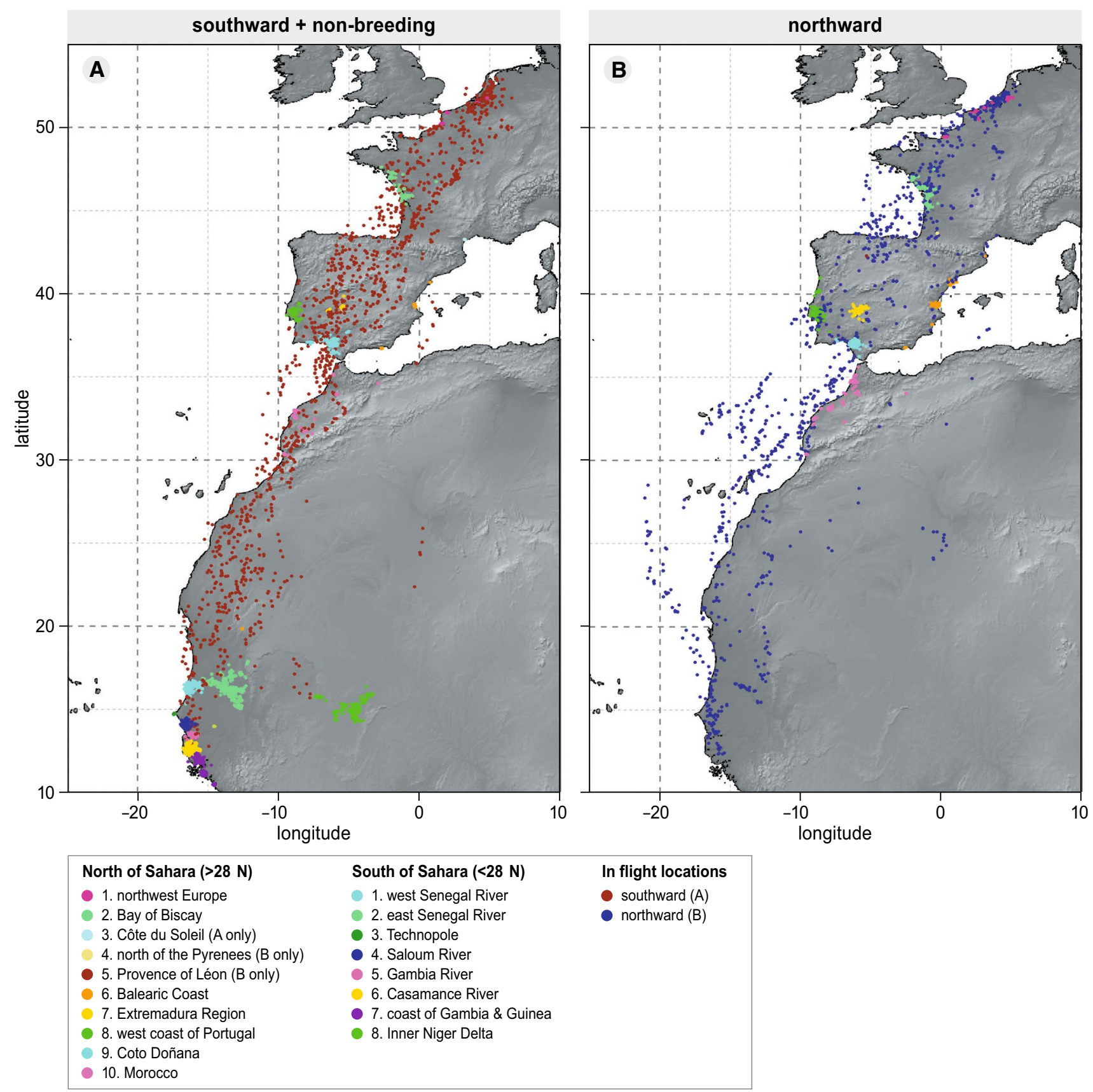

Fig. 1 Presentation of the data collected and analysed in this study. Red dots in $\mathbf{a}$ and blue dots in $\mathbf{b}$ show the in-flight locations. The other dots show the stationary locations, and are coloured by geo- graphic region. On northward migration (b), there is a single red dot in the province of Léon in northern Spain and a single khaki dot just north of the French Pyrenees were able to formally test whether the mean longitudinal distribution on northward migration varied between latitudinal boundaries. For this, we used the non-parametric Kruskal-Wallis test, which indicated that longitudinal distribution differed at different latitudinal boundaries. We made pairwise comparisons of all means using a Dunn test, which is part of the R package "dunn.test" (Dinno
2017), while applying a Benjamini-Hochberg adjustment to adjust the $p$ values for multiple comparisons.

In all other cases-southward longitudinal distribution and both southward and northward longitudinal movement- the variances were homogeneous across latitudes, so we further analysed each case using one-way ANOVAs. When an ANOVA indicated that means varied significantly 


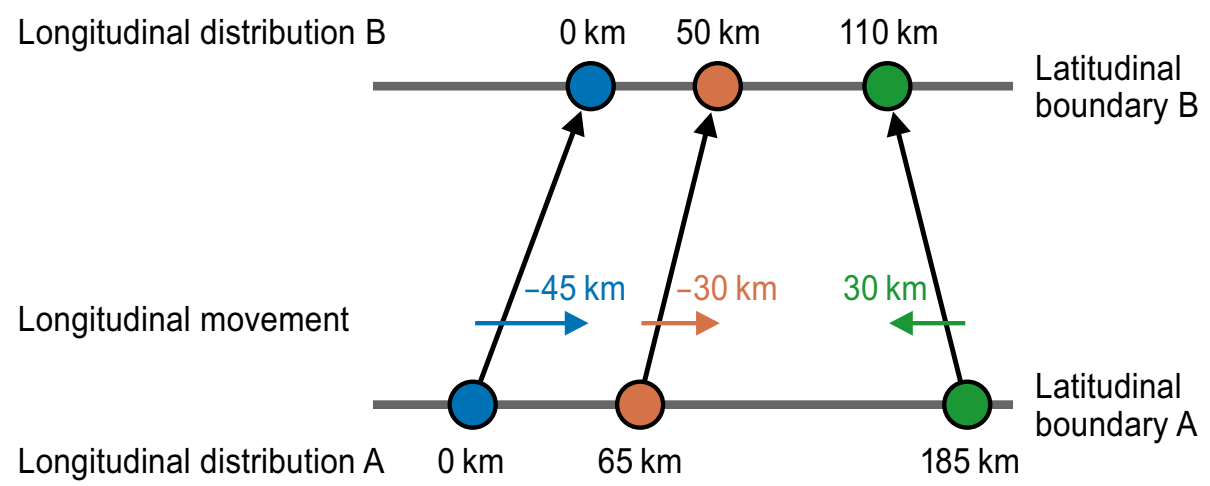

Fig. 2 Schematic overview showing how longitudinal distribution and longitudinal movement were calculated. The longitudinal distribution of tracks was calculated at each latitudinal boundary. To account for the fact that degrees of longitude differ in width at different latitudes, we expressed the longitudinal distribution as the number of kilometres between individual tracks, measured from west to east, at each latitudinal boundary. The most westerly track at each latitudinal boundary was considered to be at zero; since godwits do not

by latitude $(p<0.05)$, we made pairwise comparisons of estimated marginal means using the R package "emmeans" (Lenth 2019); we first used the function "emmeans" to compute estimated marginal means and then performed pairwise comparisons of these means while applying Tukey adjustments using the "pairs" call.

\section{Site use}

We quantified the variability in site use for two regions: (1) stopping sites north of the Sahara and (2) non-breeding sites south of the Sahara. We did this by calculating the nearestneighbour distances between all the stationary points in a focal track and all the stationary points in a comparison track (which was also done in Guilford et al. 2011; van Bemmelen et al. 2017; Oudman et al. 2018). In brief, this method takes a point in a focal track and finds the nearest point in the comparison track. Doing this for every point in the focal track results in a list of nearest-neighbour or "minimum intertrack" distances (one for every point in the focal track). This method enabled us to compare nearest-neighbour distances among all individuals across all years, among all individuals within the same year, and within the same individuals across different years.

We used the mean of all the nearest-neighbour distances within a pairwise combination as a measure of the similarity of the compared tracks. To assess whether the mean nearestneighbour distances of between-individual track comparisons within years and within-individual track comparisons between years were smaller than the mean nearest-neighbour distances between all individual tracks-i.e., to show aggregation within years and site fidelity between years (see Fig. 2 in Oudman et al. 2018)—we randomly re-assigned all migrate directly north to south, this scaling toward the most westerly track allowed us to compare the longitudinal distributions among different latitudinal boundaries. The longitudinal movement was calculated as the east-west movement of an individual between latitudinal boundaries (in kilometres). Calculating the longitudinal movement of individuals at different boundaries allowed us to evaluate whether the flight orientation of godwits differs along their migratory route

individual IDs to a track 10,000 times (Guilford et al. 2011; Oudman et al. 2018). This created a randomised estimate of mean nearest-neighbour distances for every type of track comparison. The proportion of times that a randomised estimate of track similarity is larger or smaller than the observed mean nearest-neighbour distances can then be interpreted as a two-tailed $p$ value. For this analysis, we selected the best location - based on Argos data quality—per day per individual. If there were multiple best locations for a single day, we used the first one.

We also qualitatively assessed the use of stopping and non-breeding sites by assigning location names to a geographic region (for example, the west coast of Portugal; see Fig. 1). This allowed us to discuss different stopping sites instead of just differences in kilometres between tracks. We also used this qualitative assessment to calculate the annual return rates of individuals to stopping sites. For this, we identified the sites an individual visited in a given year ( $\mathrm{t}$ ) and compared these to the sites the same individual visited in the next year $(t+1)$. We then calculated, for each site, the percentage of individuals that returned in the second year $(t+1)$. We were able to calculate these return rates for three years for autumn migration (2016-2018) and two years for spring migration (2017 and 2018).

\section{Results}

\section{Southward migration}

All 36 individuals left the breeding grounds after being tagged. In both 2015 and 2017, one individual died at a postbreeding stopping site in The Netherlands $(<150 \mathrm{~km}$ from 


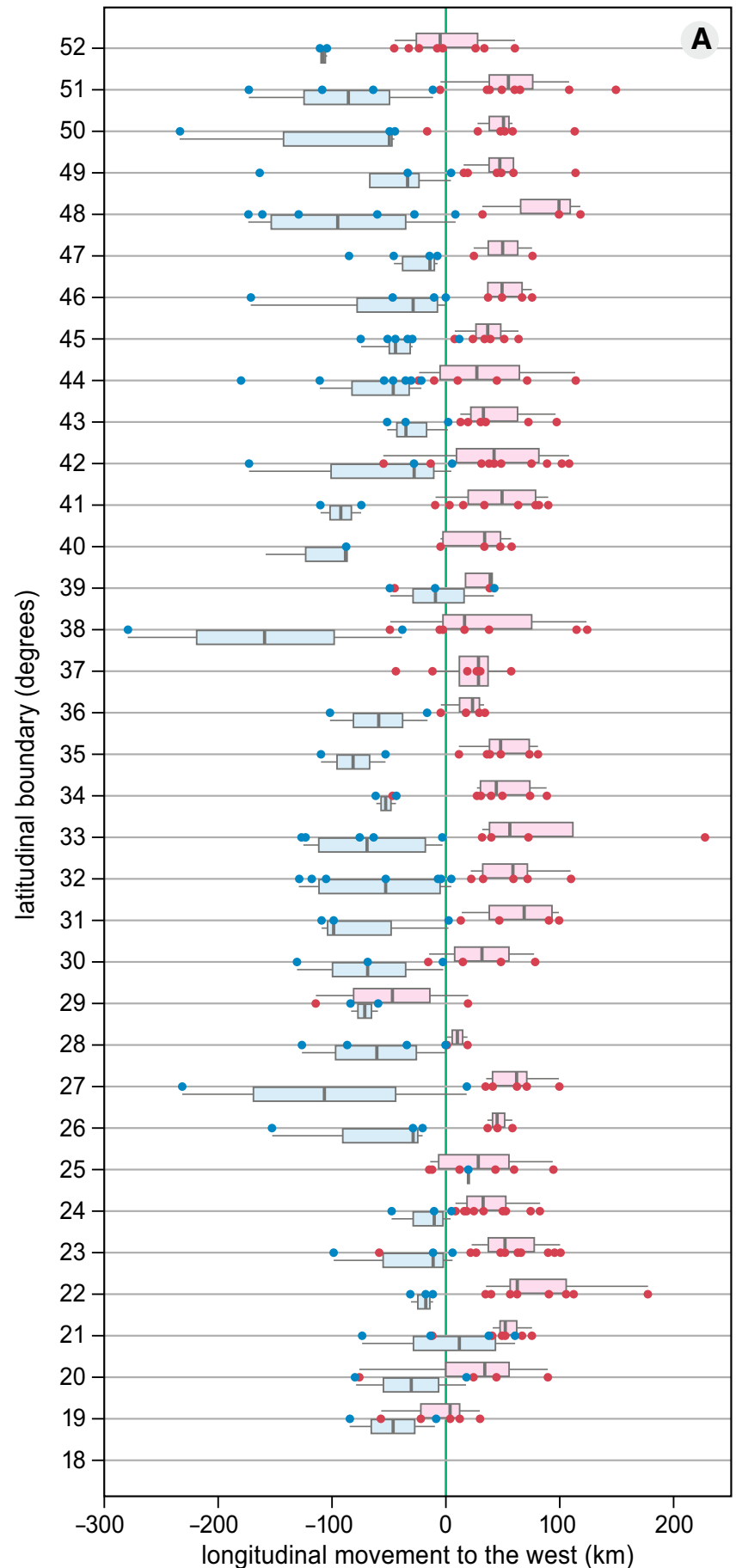

Fig. 3 A summary of the observed variation in longitudinal movement and longitudinal distribution. Boxes indicate the 25th, 50th and 75th percentile and whiskers extend to the largest value no further than 1.5 times the interquartile range away from the boxes. a Shows the longitudinal movement for each latitudinal segment on southward (red) and northward (blue) migration. The green line illustrates a

the breeding grounds) within two months of being tagged. The other 34 individuals all left The Netherlands heading toward the southwest (Figs. 1a and 3a). In 2015, one of these

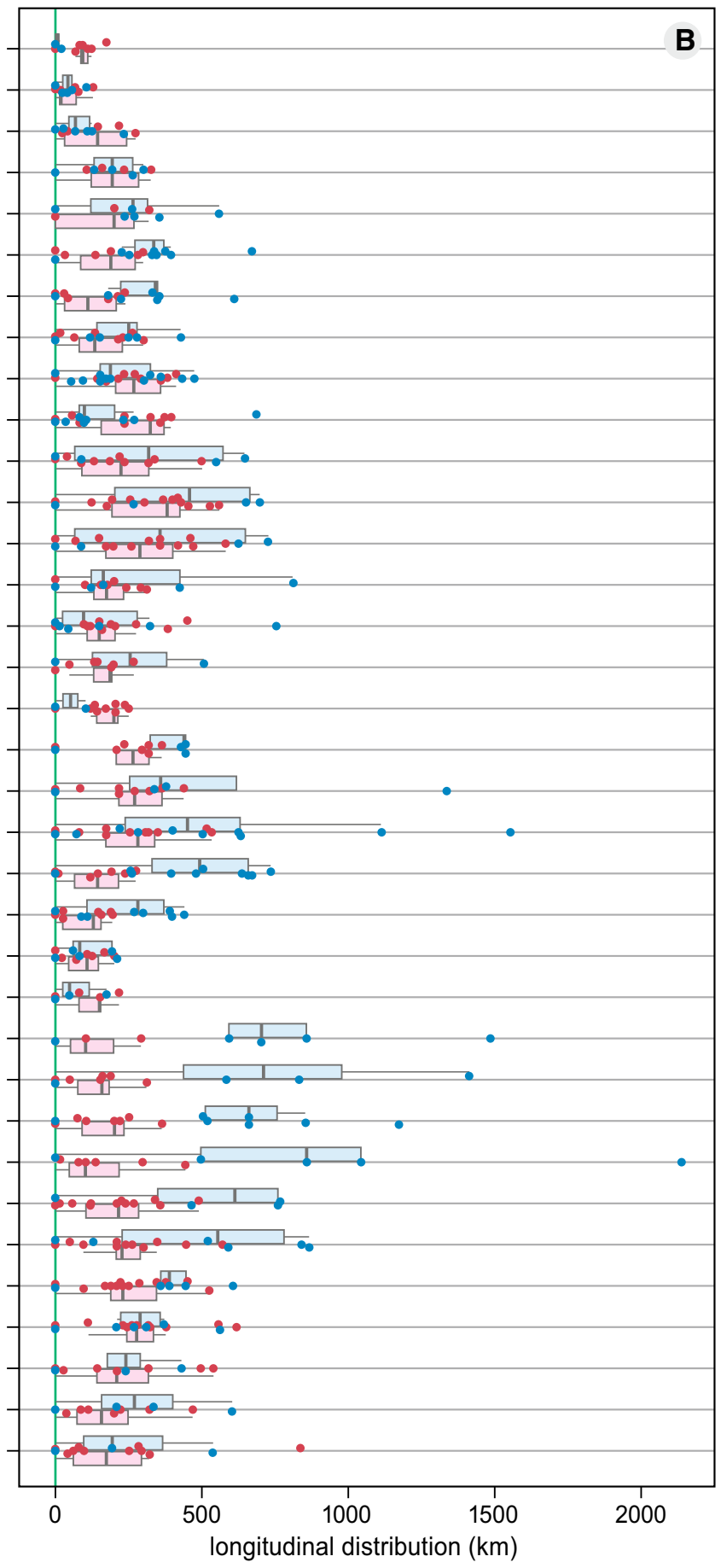

route that is directly north-south. b Shows the longitudinal distribution at each latitudinal boundary, i.e., the spatial distribution of tracks within the migratory corridor, on southward (red) and northward (blue) migration. The colours correspond to the in-flight locations in Fig. 1

individuals died during migration in Normandy, France. The other 33 individuals all reached their non-breeding sites in the year of tagging: West Africa (28 individuals, 85\%), 
Doñana, Spain (3 individuals), the west coast of Portugal (1 individual) and Morocco (1 individual). The other two occasions of mortality during southward migration happened in the years after tagging and consisted of an individual that died in Normandy, France in 2016-its tag was later discovered on the side of a cliff, which might suggest that the bird was killed by a Peregrine Falcon (Falco peregrinus) and an individual that died in 2017 on the coast of northern Spain after crossing the Bay of Biscay. In total, we observed 62 successful southward migrations from 2015 to 2018 (13 individuals with 1 track, 13 with 2 tracks, 5 with 3 tracks and 2 with 4 tracks). In 2015, one individual stopped for a night that coincided with its tag's "off" cycle. For this reason, we missed its exact stopping location on its way to West Africa and excluded this individual from the southward migration site-use analysis.

\section{Southward migration-Site use}

Godwits migrated to a variety of locations after their initial departure from The Netherlands. Two locations were used as a first destination in all four years: Doñana (22/61 southward migrations, 36\%) and the French side of the Bay of Biscay $(31 \%)$. Godwits also flew non-stop to coastal northwest Europe (7\%), the west coast of Portugal (10\%), the Extremadura region of Spain (5\%) and West Africa (5\%). Other first destinations after leaving The Netherlands were: the Balearic coast of mainland Spain (3\%), the Côte du Soleil, France $(1 \%)$ and Morocco $(1 \%)$. As a result, the distance of initial flights from The Netherlands varied considerablyfrom 80 to $4477 \mathrm{~km}(\bar{x}=1596 \pm 877 \mathrm{~km}, n=61)$. Non-breeding sites were reached directly from The Netherlands on $11 \%$ of southward migrations, reached after one stop on $38 \%$ of southward migrations, and reached after multiple stops on $52 \%$ of southward migrations. Migration routes that included an initial stop close to the breeding grounds in coastal northwest Europe and on the French side of the Bay of Biscay were especially likely to include additional stops north of the Sahara (96\%, $n=23$ flights); eventually these individuals also ended up in Doñana (65\%), the west coast of Portugal (17\%) and Morocco (13\%) before either settling for the nonbreeding period or flying on to West Africa.

Doñana and the French side of the Bay of Biscay were visited by most of the tracked individuals (Table 1). Of the 19 individuals that were followed for multiple southward migrations, one flew non-stop to West Africa in both years that it was tracked. Another individual stopped in Doñana for 5 days in one year, but flew non-stop to West Africa the next year. The remaining 17 individuals revisited stopping sites with varying consistency. Three sites were revisited in all years (2016-2018), and also had the highest average annual return rates: Doñana $(0.79,0.67-1)$, the French side of the Bay of Biscay (0.67 in all three years) and Portugal
$(0.75,0.25-1)$. Morocco was visited in 2015 by one individual which returned in 2016, and in 2017 by one individual which did not return in 2018. Northwest Europe (in 2015) and Extremadura (in 2016) were visited by two individuals, and both sites were revisited by one individual the following year. The Balearic coast of mainland Spain (2 individuals in 2015) and the Côte du Soleil (1 individual in 2016) were not revisited in the following year. The mean nearest-neighbour distance between stopping locations during southward migration of the same individual across years was $217 \mathrm{~km}$ (95\% CI 122-312), which was smaller than the distance between all tracks (306 km, 95\% CI 249-364, $p=0.002)$. This indicates that across years, stopping site use during southward migration is clearly more site-faithful than it is nomadic.

\section{Southward migration-Flights}

Throughout their southward migration, godwits oriented to the southwest; the absolute amount of longitudinal movement per degree of latitude was $u=42 \mathrm{~km} \pm 44(n=204$, Fig. 3a). The variance of these longitudinal movements did not clearly differ between latitudinal segments (Levene's test: $\left.F_{33,170}=0.883, p=0.654\right)$. The average longitudinal movement did differ somewhat between latitudinal segments $\left(F_{33,170}=1.706, p=0.016\right)$ : the average longitudinal movements from 52 to $51^{\circ} \mathrm{N}(1 \mathrm{~km} \pm 36)$ and from 29 to $28^{\circ} \mathrm{N}$ $(-47 \mathrm{~km} \pm 95)$ were more to the east than the average longitudinal movements from 22 to $21^{\circ} \mathrm{N}(82 \mathrm{~km} \pm 45 ; p<0.05$ for both pairwise comparisons), while the comparisons of average longitudinal movements for all other pairs were not different (Fig. 3a). The variation in longitudinal movement between tracks of the same individual across years was $41 \mathrm{~km} \pm 30$ (range $8-120, n=15$ repeated movements by 8 individuals).

The maximum longitudinal distribution at a latitudinal boundary ranged from $128 \mathrm{~km}\left(51^{\circ} \mathrm{N}\right)$ to $836 \mathrm{~km}\left(18^{\circ} \mathrm{N}\right.$, Fig. 3b). The average longitudinal distribution across all latitudinal boundaries was $249 \mathrm{~km} \pm 243$ ( $n=570$, Fig. 3b). The variance of these longitudinal distributions did not clearly differ across latitudes (Levene's test: $F_{34,291}=1.175$, $p=0.239$ ). The average longitudinal distribution, however, did differ by latitude $\left(F_{34,291}=2.378, p<0.001\right)$. A pairwise post hoc comparison of all means indicated that the longitudinal distribution was on average smaller at $51^{\circ} \mathrm{N}$ $(44 \mathrm{~km} \pm 43)$ than it was at $21^{\circ} \mathrm{N}, 40^{\circ} \mathrm{N}$ and $41^{\circ} \mathrm{N}$, and also that it was larger at $41^{\circ} \mathrm{N}(325 \mathrm{~km} \pm 156)$ than at $31^{\circ}$ $\mathrm{N}, 51^{\circ} \mathrm{N}$ and $52^{\circ} \mathrm{N}$ (see also Fig. $3 \mathrm{~b}$ ); for all other pairs of latitudinal boundaries, comparisons of the mean longitudinal distributions were not clearly different. That the longitudinal distribution was smaller at $51^{\circ} \mathrm{N}$ was likely the result of multiple godwits leaving from a single or several nearby post-breeding sites in The Netherlands $\left(\sim 52^{\circ} \mathrm{N}\right)$, 
Fig. 4 Repeated tracks of three individuals, "Kollum", "Lollum" and "Abbegea", in West Africa. These tracks illustrate the high site fidelity and individuality shown in the use of non-breeding sites south of the Sahara $\left(<28^{\circ} \mathrm{N}\right)$. Colours represent different years: green $=$ winter 2015/16; pink $=2016 / 17$; red $=2017 / 18$. All tracks south of the Sahara $\left(<28^{\circ} \mathrm{N}\right)$ are presented in Suppl. Fig. 1

whereas $21^{\circ} \mathrm{N}, 40^{\circ} \mathrm{N}$ and $41^{\circ} \mathrm{N}$ are all near the end of non-stop flights to stopping and non-breeding sites, when differences in longitudinal movement may have accumulated en route. The largest longitudinal distribution, with $836 \mathrm{~km}$ between individuals at $18^{\circ} \mathrm{N}$, was measured during the southward migration of the only tracked godwit that spent the non-breeding period in the Inner Niger Delta, Mali; this area lies approximately $1000 \mathrm{~km}$ inland from coastal West Africa, where all the other tracked godwits spent the nonbreeding season (Fig. 1A). The average longitudinal distribution between repeated tracks of the same individuals was $129 \mathrm{~km} \pm 88$ (range $1-299 \mathrm{~km}, n=36$ boundary crossings by 11 individuals).

\section{Non-breeding period south of the Sahara}

Twenty-eight of 33 individuals crossed the Sahara to spend part of their non-breeding period in West Africa (Fig. 1a). They visited eight wetland complexes, including (1) the Inner Niger Delta in Mali (1 individual; see above) and a network of sites in coastal West Africa: (2) the west and (3) east Senegal River, in Senegal and Mauritania, (4) Technopole, in Senegal, (5) the Saloum River, in Senegal, (6) the Gambia River, in The Gambia, (7) the Casamance River, in Senegal, and (8) multiple rivers on the coast of GuineaBissau and Guinea, including the Cacheu, Mansoa and Geba (see Fig. 1a). Two individuals visited up to five of the seven coastal sites within the non-breeding period, whereas five individuals stayed at one site during their stay in West Africa. (Fig. 4 and Suppl. Fig. 1). The average number of sites used per individual per year was $2.36 \pm 1.00$.

In total, we collected data for 45 southward Sahara crossings by 28 individuals. Three of these tracks are from one individual that flew to the Inner Niger Delta in all years it was tracked. The other 42 tracks are from individuals that all went to the network of sites in coastal West Africa and arrived at the west Senegal River (23 out of 42 tracks), the east Senegal River (9 times), the Casamance River (7 times), or the Saloum River (3 times). No individual flew directly to the rivers on the coast of Guinea-Bissau and Guinea, which is the most southerly site. All individuals were consistent across years in whether they crossed the Sahara or not ( $n=19$ individuals with repeated southward tracks). Individual site-use consistency is best illustrated by the quantitative analysis in the paragraph below, but on a more qualitative scale, the average individual site-use consistency
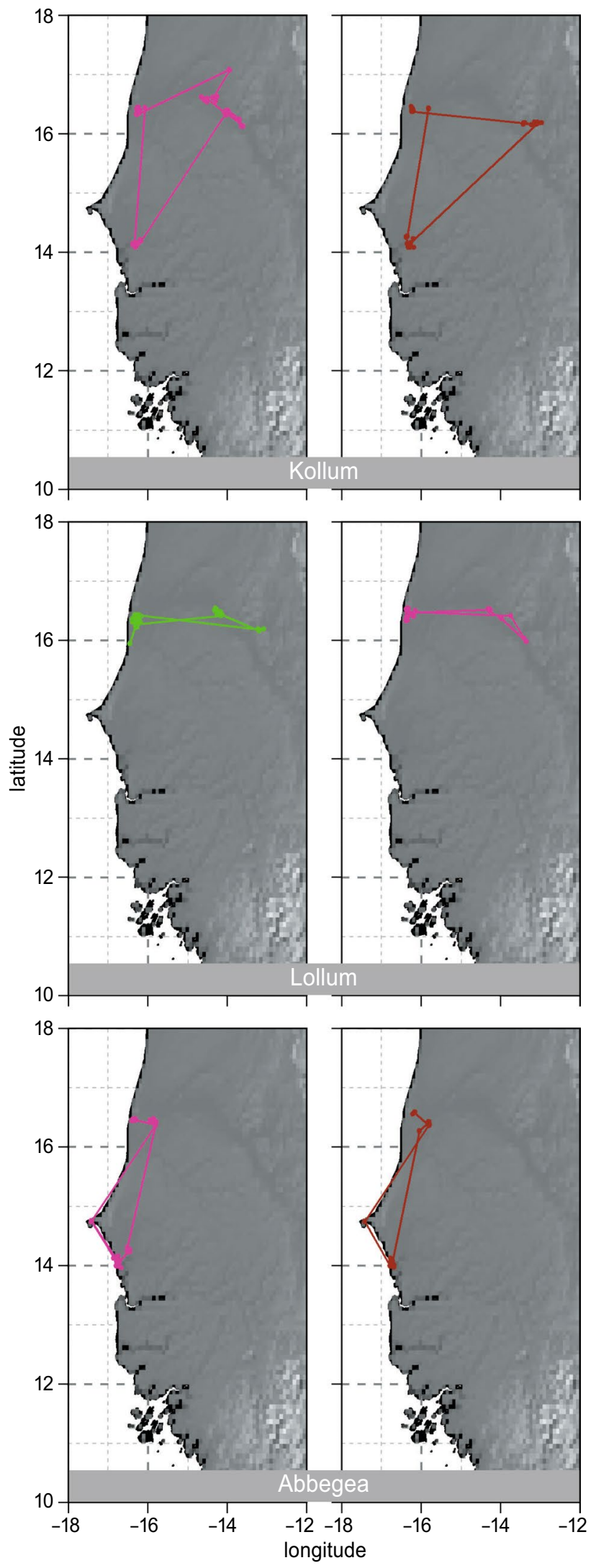
was 98\% (30 tracks from 14 individuals that crossed the Sahara). Due to the behaviour of two individuals, site-use consistency was not $100 \%$ : one bird used four sites in 2015 , but in 2016 added a stop on the Saloum River for a total of five sites; another bird used four sites in 2015, arriving at the east Senegal River after crossing the Sahara, but in 2016 skipped this site and flew directly to the Casamance River for a total of only three sites. The other 12 individuals were entirely consistent in their use of the wetland complexes during the non-breeding period and they visited the same locations in every year they were tracked.

The mean nearest-neighbour distance between all individuals south of the Sahara across all years was $232 \mathrm{~km}$ (95\% CI 165-299) and did not differ from the mean distance between individuals within years ( $228 \mathrm{~km}, 95 \%$ CI 158-289, $p=0.792, n=45$ non-breeding tracks). However, the mean nearest-neighbour distance between all locations of the same individual across years was $16 \mathrm{~km}(95 \%$ CI $0-32)$ and differed from the mean nearest-neighbour distance between all locations of all individuals in these years ( $p<0.001, n=14$ repeated individuals). This illustrates the site fidelity and idiosyncratic use of the different non-breeding sites by godwits in West Africa. When the individual that went to the Inner Niger Delta is excluded, the mean distance between all individuals across all years decreases to $156 \mathrm{~km}(95 \%$ CI 113-201), and the mean distance between individuals within years decreases to $157 \mathrm{~km}$ (95\% CI 113-199). These distances are not different ( $p=0.942, n=42$ non-breeding tracks), which again shows that there are no clear annual differences in site use. With the Inner Niger Delta individual excluded, the mean distance between all locations of the same individual across all years decreases to $11 \mathrm{~km}(95 \%$ CI $0-23$ ) and remains different from the mean distance between all locations ( $p<0.001,13$ repeated individuals), thus suggesting strong site fidelity across years.

\section{Northward migration-Site use}

From 2016 to 2018, we observed 30 successful northward Sahara crossings by 21 individuals. Most birds that crossed the Sahara arrived in Morocco (37\%) and Doñana (33\%), while others arrived at the west coast of Portugal (20\%), the Balearic coast of mainland Spain (7\%) and the Extremadura region (3\%; Fig. 1b). At these sites, other tagged godwits were already present (Morocco (1), Doñana (1), and the west coast of Portugal (3)), having spent the non-breeding period north of the Sahara. However, no godwit, including those individuals that spent the non-breeding period north of the Sahara, flew directly to the Netherlands. This means that the minimum number of stopping sites was 1 , while the average was $3.02 \pm 1.42$ and the maximum was $6(n=2$ individuals). All 11 godwits that arrived in Morocco continued on to Doñana.

As was the case for southward migration, Doñana and the French side of the Bay of Biscay were visited by most of the tracked individuals (Table 1). The 12 individuals that were followed for multiple northward migrations revisited their stopping sites with varying consistency. The annual return rate was 1 for the west coast of Portugal and the Balearic coast of mainland Spain in both 2017 and 2018. Doñana ( 0.5 in 2017, 0.75 in 2018), the French side of the Bay of Biscay $(0.83,1)$, northwest Europe $(1,0.5)$ and the Extremadura Region $(1,0)$ were less likely to be revisited. Morocco $(0,0)$ was never revisited by the same individual either in the following year or in any other year. The mean nearestneighbour distance between stopping locations of the same individual across years was $139 \mathrm{~km}$ (95\% CI 64-214), which was smaller than the distance between all tracks $(282 \mathrm{~km}$, 95\% CI $241-324, p=0.001)$. This indicates that across years, stopping site use during northward migration is more site-faithful than it is nomadic.

\section{Northward migration-flights}

Throughout their northward migration, godwits oriented to the northeast. The absolute amount of longitudinal movement per degree of latitude averaged $-59 \mathrm{~km} \pm 62(n=113$, Figs. $1 \mathrm{~b}$ and $3 \mathrm{a}$ ). The variance of these longitudinal movements did not clearly vary by latitudinal segment (Levene's test: $\left.F_{32,80}=1.194, p=0.259\right)$, nor did the average longitudinal movements $\left(F_{32,80}=0.891, p=0.634\right)$. The difference in longitudinal movement between tracks of the same individual across years was $69 \mathrm{~km} \pm 54$ (range 7-145, $n=6$ repeated movements by 5 individuals).

The maximum longitudinal distribution at a given latitudinal boundary ranged from $3 \mathrm{~km}\left(51^{\circ} \mathrm{N}\right)$ to $2140 \mathrm{~km}$ $\left(25^{\circ} \mathrm{N}\right)$. The variances of these longitudinal distributions differed between latitudes (Levene's test: $F_{34,173}=2.065$, $p=0.001$ ). A visual inspection of Figs. $1 \mathrm{~b}$ and $3 \mathrm{~b}$ and the variance at each latitudinal boundary suggested that the variance was large at latitudes $25^{\circ} \mathrm{N}, 27-28^{\circ} \mathrm{N}$, and 33-34 $\mathrm{N}(\mathrm{SD}>450 \mathrm{~km})$. We believe the tracks at these latitudes were more widely distributed because some individuals flew over the Atlantic Ocean, some followed the coast, and others flew inland (Figs. $1 \mathrm{~b}$ and $3 \mathrm{~b}$ ). At latitudes $51^{\circ} \mathrm{N}$ and $52^{\circ} \mathrm{N}$, the variance was especially small $(\mathrm{SD}<50 \mathrm{~km})$, probably because individuals were converging on the same breeding site $\left(\sim 52^{\circ} \mathrm{N}\right)$. Those latitudes that appear to have an especially large or small variance are likely the latitudes that cause the Levene's test to show that variances differ across latitudinal segments; this notion is supported by the fact that when these latitudes are excluded from the Levene's test, the variances are homogeneous among the remaining 
latitudinal segments $\left(F_{27,140}=1.380, p=0.118\right)$. Nevertheless, these visual comparisons of the variance at different latitudes are not based on a formal test and should be interpreted with care.

The average longitudinal distributions across all latitudes was $325 \mathrm{~km} \pm 330(n=208$, Fig. 3b) and varied by latitude $(H(34)=57.874, p=0.007)$. A post hoc Dunn pairwise comparison that adjusted $p$-values for multiple comparisons indicated that no latitudes were different from each other ( $p>0.05$ for all pairwise comparisons). The longitudinal distribution between tracks of the same individual was on average $195 \mathrm{~km} \pm 227$ (range $1-895 \mathrm{~km}, n=16$ boundary crossings by 8 individuals). The largest longitudinal distribution within tracks of the same individual was $895 \mathrm{~km}$ at $33^{\circ}$ $\mathrm{N}$ (northern Morocco).

\section{Discussion}

Our study describes natural variation throughout the annual cycle in the spatial distribution of adult Black-tailed Godwits that breed within a kilometre of each other in The Netherlands. Our results confirm the previous findings of less extensive tracking studies of godwits breeding in The Netherlands (Hooijmeijer et al. 2013; Senner et al. 2019), showing that godwits: (1) migrate southwest and northeast along the same relatively straight, narrow corridor on southward and northward migration, (2) exhibit large individual variation in the distances and duration of their flights, (3) use a network of sites across Western Europe, the Mediterranean, and West Africa (including the Inner Niger Delta), and (4) spend the non-breeding period in the Mediterranean or West Africa. Our results also confirm that godwits are present in the Doñana wetlands in southern Spain during the entire non-breeding period (Table 1), as was previously documented by Márquez-Ferrando et al. (2014).

However, our tracking study also substantially extends our understanding of godwit migration by identifying additional sites used during migration and the non-breeding period. These include sites along the northwest coast of mainland Europe (the English Channel and North Sea), the Balearic coast of mainland Spain (including the wetlands and rice fields in the Ebro Delta and L'Albufera), and the Saloum and Gambia rivers (in Senegal and The Gambia, respectively). Although it was already known that godwits use a network of sites across Western Europe and the Mediterranean (Lourenço and Piersma 2008), previous studies have focused mostly on Doñana (Márquez-Ferrando et al. 2014), the Extremadura region (Masero et al. 2011), and the west coast of Portugal (Lourenço et al. 2010). Our results clearly illustrate the additional importance of Morocco, the Balearic coast of mainland Spain, and the French side of the Bay of Biscay.
Importantly, our study also illuminates another previously unknown aspect of godwit migration. Just as godwits exhibit significantly more variation in migratory timing at the population level compared to the individual level (Verhoeven et al. 2019), our results show that the godwit population as a whole uses a broad network of sites during both south- and northward migration, but that individual godwits are relatively consistent in their site use north of the Sahara and exhibit high site fidelity and individuality in their use of non-breeding sites in West Africa. The fact that individuals return to the same sites probably also explains why the observed longitudinal distributions are somewhat smaller within tracks of single individuals than at the population level. In contrast, however, Morocco was visited by a large proportion of our tracked individuals during northward migration, but was never revisited by the same individual across years. We speculate that godwits coming from West Africa do not attempt to fly to Morocco as a destination, but only stop there out of necessity after encountering headwinds en route (see Loonstra et al. 2019b). Even though such "emergency" stopping sites (Shamoun-Baranes et al. 2010) may be used intermittently, they could be of critical importance for the survival of long-distance migrants.

\section{Applied considerations}

In mapping the distribution of godwits across seasons and years in the mid-2010s, we have: (1) identified previously unknown and possibly new sites, (2) revealed that individual godwits differ in which sites they use and (3) demonstrated that godwits show fidelity to these sites. Some of this information can contribute directly to conservation measures; for example, we now realise that any management of stopping and non-breeding sites used by godwits should be applied not only to the well-studied sites across the Iberian Peninsula, but also to sites in Morocco, the Balearic coast of mainland Spain, and the French side of the Bay of Biscay.

However, further work will be needed to effectively maintain or restore stopping and non-breeding sites-a "high priority" goal according to the International Single Species Action Plan for the Conservation of the Black-tailed Godwit (Jensen et al. 2008). Tracked locations must first be put into context-researchers need to begin developing an understanding of why godwits use certain sites, why consistency in site use differs between stopping sites, and what godwits are doing in each place. This will require groundbased methods that gather a great deal of additional information about the habitat characteristics and godwit use at sites across the migratory route (Schlaich et al. 2016; Chan et al. 2019b). For example, that godwits consistently use different sites in West Africa during different times of year is an opportunity to compare those different habitats at different time points and in this way gain insight into the ecological 
basis of the godwit distributions we have already been able to observe. Certain insights could potentially be extrapolated over the entire range by using remote sensing (Howison et al. 2020, in revision). These exciting possibilities would have valuable implications for conservation efforts-but it is important to realize they are all wholly reliant on first building a detailed description of godwit spatial distribution. Only with such a foundation can we begin to ask the right questions and measure the right parameters.

\section{Population variation in space use}

Our detailed description of the natural variation in the migratory routines of godwits allows us to compare migratory behaviour among different species, populations and individuals. The high site fidelity and individuality of godwits in their use of non-breeding sites is similar to that of other migratory shorebirds such as Northern Lapwing (Vanellus vanellus; Eichhorn et al. 2017), Red-Necked Phalaropes (Phalaropus lobatus; van Bemmelen et al. 2019), Icelandic Black-tailed Godwits (Limosa limosa islandica; Gill et al. 2019), Marbled Godwits (Limosa fedoa; Ruthrauff et al. 2019), and Eurasian Woodcock (Scolopax rusticola; Tedeschi et al. 2019). It is also similar to species such as the Marsh Harrier (Circus aeruginosus; Strandberg et al. 2008), Whinchat (Saxicola rubetra; Blackburn and Cresswell 2015) and Montagu's Harrier (Circus pygargus; Schlaich et al. 2020), all of which, like godwits, use the East-Atlantic Flyway and the Sahel zone.

With this information, we can begin exploring the ecological basis for the variation in migratory routines among these and other species. For example, the long-distance migratory birds on this non-exhaustive list all have distinct life-history strategies, including considerably different mating systems, diets, densities, flight behaviours, and migration routes. This is consistent with the idea that high site fidelity and individuality in the use of non-breeding sites is relatively common among long-distance migratory birds (see Cresswell 2014). However, among the birds that use the East-Atlantic Flyway to travel to the Sahel zone, there are also species with nomadic non-breeding movements (e.g., White Storks (Ciconia ciconia); Berthold et al. 2002) and low non-breeding site fidelity (e.g., European Hoopoes (Upupa epops); van Wijk et al. 2016). There is therefore a gradient in site-use behaviour among long-distance migrants ranging from nomadic to strongly site-faithful.

A similar gradient exists in the spatial distribution of actively migrating birds. For example, when crossing the Sahara, the longitudinal distribution of godwits is similar to that of Marsh Harriers but narrower than that of Ospreys (Pandion haliaetus) and Egyptian Vultures (Neophron percnopterus) (Lopez-Lopez et al. 2014; Vardanis et al. 2016). Even within the Continental Black-tailed Godwit subspecies, there is variation along this gradient: comparing our results to Loonstra et al. (2019c) shows that Polish godwits exhibit higher within- and between-individual variation in space use during migration than Dutch godwits. Such variation among and within species begs the question: what causes these differences?

Given the large variation in space use of migratory birds among continents, flyways, life-history strategies and migratory behaviours (e.g., Finch et al. 2017), differing space use among species is likely not a simple matter of broad ecological differences (such as between passerines vs. raptors, insectivores vs. carnivorous, or short-lived vs. long-lived species). Instead, space use is likely to be species- or even population specific. In the case of Polish versus Dutch godwits, for example, the ways in which social information is transmitted among individuals may be different between the high-density Dutch population and the low-density Polish population, and this may lead to different levels of canalization of migratory routines (see Loonstra et al. 2019c for a more extensive discussion). The fact that migratory routines are likely not based simply on broad ecological differences supports recent calls to study the full annual cycle of different species, and stresses the need to combine the nonbreeding and migration ecology of a given species with its population dynamics to better understand the observed differences among species, and in this way effectively inform conservation measures (Marra et al. 2015; Rushing et al. 2017; Cresswell 2018).

At the same time, however, tracking the same individuals across years (e.g., Eichhorn et al. 2017; Ruthrauff et al. 2019) is making it increasingly clear that individuality in space use is common within species. This means that space use is not only species- or population specific, but also specific to individuals. Because individuals from the same population likely have a generally similar genetic background, the observed individual differences are not likely to be of a purely genetic origin. For example, the godwits we tracked breed within a kilometre of each other in an area where natal dispersal was found to be $915 \mathrm{~m}$ (95\% CI 550-1515 m, Kentie et al. 2014). This means the most likely cause for the individuality we observed is that migratory birds have the phenotypic plasticity to develop differences in migratory routines (sensu Piersma and Drent 2003). This idea is supported by a growing number of studies that have shown agedependent strategies among migratory birds by (1) tracking juveniles throughout their development, and (2) making comparisons between adults and juveniles tracked in the same year (e.g., Perdeck 1958; Hake et al. 2003; Chernetsov et al. 2004; Lok et al. 2011; Mueller et al. 2013; Gill et al. 2014; Sergio et al. 2014; Rotics et al. 2016; Meyburg et al. 2017; Vansteelant et al. 2017; Verhoeven et al. 2018). This suggests that, in addition to studying the full annual cycle of a population, researchers need to acquire lifelong tracks of 
individual birds to help identify the mechanistic processes behind the observed variation in adult migration routes. This information will enable researchers to predict whether and how fast a population can adjust to altered surroundings and, as such, is also essential to developing effective conservation measures (Reynolds et al. 2017; Senner et al. 2020).

Acknowledgements We would like to thank the following people for their help with catching and tagging: Wiebe Kaspersma, Lara Mielke, Renate de Boer, Zhu Bingrun, Iris Bontekoe, Michael Meijer, Wender Bill, Ana Coelho, Daniel da Costa Lopes, Femke Roig Kuhn and Sarah Lakke. We thank Jos Hooijmeijer for curating our research database, Tienke Koning for fundraising, and Julie Thumloup and Yvonne Verkuil for their help with the molecular sexing. We thank Thomas Oudman for sharing his R code and helping us with the nearest-neighbour analysis, and Rob van Bemmelen for sharing his $\mathrm{R}$ code for the nearest-neighbour analysis. We thank Dick Visser for greatly improving our figures, and are grateful to Camilo Carneiro, Tomas Gunnarson, Dmitry Kishkinev and an anonymous reviewer for their constructive comments that improved the manuscript. The late Sikke Venema, as well as Anton Stokman, Wiebe Nauta and Staatsbosbeheer Súdwest Fryslân, kindly allowed us access to their lands. This work was funded by the Spinoza Premium 2014 of the Netherlands Organization for Scientific Research (NWO) awarded to TP, with additional funding from an anonymous donor, the Ubbo Emmius Fund and the GieskesStrijbis Fonds. This research was conducted under license numbers 6350G and AVD105002017823 following the Dutch Animal Welfare Act Articles 9 and 11.

Open Access This article is licensed under a Creative Commons Attribution 4.0 International License, which permits use, sharing, adaptation, distribution and reproduction in any medium or format, as long as you give appropriate credit to the original author(s) and the source, provide a link to the Creative Commons licence, and indicate if changes were made. The images or other third party material in this article are included in the article's Creative Commons licence, unless indicated otherwise in a credit line to the material. If material is not included in the article's Creative Commons licence and your intended use is not permitted by statutory regulation or exceeds the permitted use, you will need to obtain permission directly from the copyright holder. To view a copy of this licence, visit http://creativecommons.org/licenses/by/4.0/.

\section{References}

Alerstam T, Hedenström A, Åkesson S (2003) Long-distance migration: evolution and determinants. Oikos 103:247-260

Alves JA, Gunarsson TG, Hayhow DB, Appleton GF, Potts PM, Sutherland WJ, Gill JA (2013) Costs, benefits, and fitness consequences of different migratory strategies. Ecology 94:11-17

Berthold P, Van Den Bossche W, Jakubiec Z, Kaatz C, Kaatz M, Querner U (2002) Long-term satellite tracking sheds light upon variable migration strategies of white storks (Ciconia ciconia). J Ornithol 143:489-495

Blackburn E, Cresswell W (2015) High winter site fidelity in a longdistance migrant: Implications for wintering ecology and survival estimates. J Ornithol 157:93-108

Chan Y-C, Peng H-B, Han Y-X, Chung SS-W, Li L, Zhang L, Piersma $\mathrm{T}$ (2019a) Conserving unprotected important coastal habitats in the Yellow Sea: Shorebird occurrence, distribution and food resources at Lianyungang. Glob Ecol Cons 20:e00724
Chan Y-C, Tibbitts TL, Lok T, Hassell CJ, Peng H-B, Ma Z, Zhang Z, Piersma T (2019b) Filling knowledge gaps in a threatened shorebird flyway through satellite tracking. J Appl Ecol 56:2305-2315

Chernetsov N, Berthold P, Querner U (2004) Migratory orientation of first-year white storks (Ciconia ciconia): inherited information and social interactions. J Exp Biol 207:937-943

Cresswell W (2014) Migratory connectivity of Palaearctic-African migratory birds and their responses to environmental change: the serial residency hypothesis. Ibis 156:493-510

Cresswell W (2018) The continuing lack of ornithological research capacity in almost all of West Africa. Ostrich 89:123-129

Dinno A (2017) dunn.test: Dunn's test of multiple comparisons using rank sums. https://CRAN.R-project.org/package=dunn.test. Accessed 11 Apr 2019

Douglas DC, Weinzierl R, Davidson SC, Kays R, Wikelski M, Bohrer G (2012) Moderating Argos location errors in animal tracking data. Meth Ecol Evol 3:999-1007

Eichhorn G, Bil W, Fox JW (2017) Individuality in northern lapwing migration and its link to timing of breeding. J Avian Biol 48:1132-1138

Finch T, Butler SJ, Franco AMA, Cresswell W (2017) Low migratory connectivity is common in long-distance migrant birds. J Anim Ecol 86:662-673

Fox J, Weisberg S (2019) An (R) companion to applied regression, 3rd edn. Sage, Thousand Oaks

Gill JA, Langston RHW, Alves JA, Atkinson PW, Bocher P, Vieira NC, Crockford NJ, Gélinaud G, Groen N, Gunnarsson TG, Hayhow B, Hooijmeijer J, Kentie R, Kleijn D, Lourenço PM, Masero JA, Meunier F, Potts PM, Roodbergen M, Schekkerman H, Schröder J, Wymenga E, Piersma T (2007) Contrasting trends in two blacktailed godwit populations: a review of causes and recommendations. Wader Study Group Bull 114:43-50

Gill JA, Alves JA, Sutherland WJ, Appleton GF, Potts PM, Gunnarsson TG (2014) Why is timing of bird migration advancing when individuals are not? Proc R Soc B 281:20132161

Gill JA, Alves JA, Gunnarsson TG (2019) Mechanisms driving phenological and range change in migratory species. Philos Trans $\mathrm{R}$ Soc B 374:20180047

Guilford T, Freeman R, Boyle D, Dean B, Kirk H, Phillips R, Perrins C (2011) A dispersive migration in the Atlantic puffin and its implications for migratory navigation. PLoS ONE 2011:6

Hake M, Kjellen N, Alerstam T (2003) Age-dependent migration strategy in honey buzzards Pernis apivorus tracked by satellite. Oikos 103:385-396

Hijmans RJ (2017) Geosphere: spherical trigonometry. R package version 1.5-7. https://CRAN.R-project.org/package=geosphere. Accessed 24 Sept 2018

Hooijmeijer JCEW, Senner NR, Tibbitts TL, Gill RE Jr, Douglas DC, Bruinzeel L, Wymenga E, Piersma T (2013) Post-breeding migration of Dutch-breeding black-tailed godwits: timing, routes, use of stopovers, and nonbreeding destinations. Ardea 101:141-152

Howison RA, Masero JA, Olf H, Hooijmeijer JCEW, Loonstra AHJ, Senner NR, Tittonell P, Verhoeven MA, Piersma T (2020) Migratory black-tailed godwits as sentinels of wetland ecological integrity in the western Sahel. Scientific Reports (in revision)

Jensen FP, Béchet A, Wymenga E (2008) International single species action plan for the conservation of black-tailed Godwit Limosa 1. Limosa \& L. 1. Islandica. AEWA technical series no. 37. Bonn, Germany

Kentie R, Both C, Hooijmeijer JCEW, Piersma T (2014) Age-dependent dispersal and habitat choice in black-tailed godwits Limosa limosa limosa across a mosaic of traditional and modern grassland habitats. J Avian Biol 45:396-405

Kentie R, Marquez-Ferrando R, Figuerola J, Gangoso L, Hooijmeijer JCEW, Loonstra AHJ, Robin F, Sarasa M, Senner N, Valkema H, Verhoeven MA, Piersma T (2017) Does wintering north or south 
of the Sahara correlate with timing and breeding performance in black- tailed godwits? Ecol Evol 7:2812-2820

Lenth R (2019) emmeans: estimated marginal means, aka leastsquares means. https://CRAN.R-project.org/package=emmeans.. Accessed 25 Feb 2019

Lok T, Overdijk O, Tinbergen JM, Piersma T (2011) The paradox of Spoonbill migration: most birds travel to where survival rates are lowest. Anim Behav 82:837-844

Lok T, Overdijk O, Piersma T (2015) The cost of migration: spoonbills suffer higher mortality during trans-Saharan spring migrations only. Biol Lett 11:20140944

Loonstra AHJ, Verhoeven MA, Senner NR, Hooijmeijer JCEW, Piersma T, Kentie R (2019a) Natal habitat and sex-specific survival rates result in a male-biased adult sex ratio. Behav Ecol 30:843-851

Loonstra AHJ, Verhoeven MA, Senner NR, Both C, Piersma T (2019b) Adverse wind-conditions during northward Sahara crossings increase the in-flight mortality of Black-tailed Godwits. Ecol Lett 22:2060-2066

Loonstra AHJ, Verhoeven MA, Zbyryt A, Schaaf E, Both C, Piersma $\mathrm{T}$ (2019c) Individual long-distance migratory shorebirds do not necessarily stick to single routes: an hypothesis on how low population densities decrease social conformity. Ardea 107:251-261

Lopez-Lopez P, Garcia-Ripolles C, Urios V (2014) Individual repeatability in timing and spatial flexibility of migration routes of transSaharan migratory raptors. Curr Zool 60:642-652

Lourenço PM, Piersma T (2008) Changes in the non-breeding distribution of continental black-tailed godwits Limosa limosa limosa over 50 years: a synthesis of surveys. Wader Study Group Bull 115:91-97

Lourenço PM, Kentie R, Schroeder J, Alves JA, Groen NM, Hooijmeijer JCEW, Piersma T (2010) Phenology, staging dynamics and population size of migrating black-tailed godwits Limosa limosa limosa in Portuguese rice plantations. Ardea 98:35-42

Marra PP, Cohen EB, Scott R, Rutter J, Tonra CM (2015) A call for annual cycle research in animal ecology. Biol Lett 14:20150552

Márquez-Ferrando R, Figuerola J, Hooijmeijer JCEW, Piersma T (2014) Recently created man-made habitats in Doñana provide alternative wintering space for the threatened Continental European black-tailed godwit population. Biol Conserv 171:127-135

Masero JA, Santiago-Quesada F, Sánchez-Guzmán JM, Villegas A, Abad-Gómez JM, Lopes RJ, Encarnação V, Corbacho C, Morán $R$ (2011) Long lengths of stay, large numbers, and trends of the black-tailed godwit Limosa limosa in rice fields during spring migration. Bird Conserv Internat 21:12-24

McKinnon EA, Love OP (2018) Ten years tracking the migrations of small landbirds: lessons learned in the golden age of bio-logging. Auk 135:834-856

Mellone U, Klaassen RHG, García-Ripollés C, Limiñana R, LópezLópez P, Pavón D, Strandberg R, Urios V, Vardakis M, Alerstam $T$ (2012) Interspecific comparison of the performance of soaring migrants in relation to morphology, meteorological conditions and migration strategies. PLoS ONE 7:e39833

Meyburg B-U, Bergmanis U, Langgemach T, Graszynski K, Hinz A, Börner I, Meyburg C, Vansteelant WMG (2017) Orientation of native versus translocated juvenile lesser spotted eagles (Clanga pomarina) on the first autumn migration. J Exp Biol 220:2765-2776

Mueller T, O'Hara RB, Converse SJ, Urbanek RP, Fagan WF (2013) Social learning of migratory performance. Science 341:999-1002

Newton I (2008) The migration ecology of birds. Academic Press, London

Oudman T, Piersma T, Salem MVA, Feis ME, Dekinga A, Holthuijsen S, ten Horn J, van Gils JA, Bijleveld AI (2018) Resource landscapes explain contrasting patterns of aggregation and site fidelity by red knots at two wintering sites. Mov Ecol 6:24
Perdeck AC (1958) Two types of orientation in migrating starlings Sturnus vulgaris L. and Chaffinches Fringilla coelebs L., as revealed by displacement experiments. Ardea 46:1-37

Piersma T, Baker AJ (2000) Life history characteristics and the conservation of migratory shorebirds. In: Gosling LM, Sutherland WJ (eds) Behaviour and conservation. Cambridge University Press, Cambridge, pp 105-124

Piersma T, Drent J (2003) Phenotypic flexibility and the evolution of organismal design. Trends Ecol Evol 18:228-233

Piersma T (2011) Flyway evolution is too fast to be explained by the modern synthesis: Proposals for an 'extended' evolutionary research agenda. J Ornithol 152:151-159

Piersma T, Lok T, Chen Y, Hassell CJ, Yang H-Y, Boyle A, Slaymaker M, Chan Y-C, Melville DS, Zhang Z-W, Ma Z (2016) Simultaneous declines in summer survival of three shorebird species signals a flyway at risk. J Appl Ecol 53:479-490

R Core Team (2018) R: A Language and Environment for Statistical Computing. Vienna: R Foundation for Statistical Computing. https ://www.R-project.org. Accessed 24 Sept 2018

Rakhimberdiev E, Duijns S, Karagicheva J, Camphuysen CJ, Castricum VRS, Dekinga A, Dekker R, Gavrilov A, ten Horn J, Jukema J, Saveliev A, Soloviev M, van Tibbitts TL, Gils JA, Piersma T (2018) Food abundance at refuelling sites can mitigate Arctic warming effects on a migratory bird. Nat Comm 9:4263

Reynolds MD, Sullivan BL, Hallstein E et al (2017) Dynamic conservation for migratory species. Sci Adv 3:e1700707

Rotics S, Kaatz M, Resheff YS, Turjeman SF, Zurell D, Sapir N, Eggers U, Flack A, Fiedler W, Jeltsch F, Wikelski M, Nathan $R$ (2016) The challenges of the first migration: movement and behaviour of juvenile vs. adult White Storks with insights regarding juvenile mortality. J Anim Ecol 85:938-947

Rushing CS, Hostetler JA, Sillett TS, Marra PP, Rotenberg JA, Ryder TB (2017) Spatial and temporal drivers of avian population dynamics across the annual cycle. Ecology 98:2837-2850

Rushing CS, Rubenstein M, Lyons JE, Runge MC (2020) Using value of information to prioritize research needs for migratory bird management under climate change: a case study using federal land acquisition in the United States. Biol Rev 95:1109-1130

Ruthrauff DR, Tibbitts TL, Gill RE Jr (2019) Flexible timing of annual movements across consistently used sites by Marbled Godwits breeding in Alaska. Auk 136:1-11

Schlaich AE, Klaassen RHG, Bouten W, Bretagnolle V, Koks BJ, Villers A, Both C (2016) How individual Montagu's Harriers cope with Moreau's Paradox during the Sahelian winter. J Anim Ecol 85:1491-1501

Schlaich AE, Bretagnolle V, Both C, Koks BJ, Klaassen RHG (2020) On the wintering ecology of Montagu's Harriers in West Africa: a detailed description of site use throughout the winter in relation to varying annual environmental conditions. Ardea (in press)

Schroeder J, Lourenço PM, van der Velde M, Hooijmeijer JCEW, Both C, Piersma T (2008) Sexual dimorphism in plumage and size in black-tailed godwits Limosa limosa limosa. Ardea 96:25-37

Senner NR, Verhoeven MA, Abad-Gómez JM, Gutiérrez JS, Hooijmeijer JCEW, Kentie R, Masero JA, Tibbitts TL, Piersma T (2015) When Siberia came to The Netherlands: the response of Black-tailed Godwits to a rare spring weather event. J Anim Ecol 84:1164-1176

Senner NR, Stager M, Verhoeven MA, Cheviron ZA, Piersma T, Bouten W (2018) High-altitude shorebird migration in the absence of topographical barriers: avoiding high air temperatures and searching for profitable winds. Proc R Soc B 285:20180569

Senner NR, Verhoeven MA, Abad-Gómez JM, Alves JA, Hooijmeijer JCEW, Howison RA, Kentie R, Loonstra AHJ, Masero JA, Rocha A, Stager M, Piersma T (2019) High migratory survival 
and highly variable migratory behaviour in black-tailed godwits. Front Ecol Evol 7:96

Senner NR, Morbey YE, Sandercock BK (2020) Editorial: flexibility in the migration strategies of animals. Front Ecol Evol 8:111

Sergio F, Tanferna A, De Stephanis R, Jiménez LJ, Blas J, Tavecchia G, Preatoni D, Hiraldo F (2014) Individual improvements and selective mortality shape lifelong migratory performance. Nature 515:410-413

Shamoun-Baranes J, Leyrer J, van Loon E, Bocher P, Robin F, Meunier F, Piersma T (2010) Stochastic atmospheric assistance and the use of emergency staging sites by migrants. Proc R Soc B 277:1505-1511

Strandberg R, Klaassen RHG, Hake M, Olofsson P, Thorup K, Alerstam T (2008) Complex temporal pattern of Marsh Harrier Circus aeruginosus migration due to pre- and post-migratory movements. Ardea 96:159-171

Studds C, Kendall B, Murray N et al (2017) Rapid population decline in migratory shorebirds relying on Yellow Sea tidal mudflats as stopover sites. Nat Comm 8:14895

Taylor CM, Norris DR (2007) Predicting conditions for migration: effects of density dependence and habitat quality. Biol Lett $3: 280-284$

Tedeschi A, Sorrenti M, Bottazzo M, Spagnesi M, Telletxea I, Ibàñez R, Tormen N, De Pascalis F, Guidolin L, Rubolini D (2019) Interindividual variation and consistency of migratory behavior in the Eurasian woodcock. Curr Zool 66:153-163

Trierweiler C, Klaassen RHG, Drent RH, Exo K-M, Komdeur J, Bairlein F (2014) Migratory connectivity and population-specific migration routes in a long-distance migratory bird. Proc R Soc B Biol Sci 281:1778

van Bemmelen R, Moe B, Hanssen SA, Schmidt NM, Hansen J, Lang J, Sittler B, Bollache L, Tulp I, Klaassen R, Gilg O (2017) Flexibility in otherwise consistent non-breeding movements of a longdistance migratory seabird, the long-tailed skua. Mar Ecol Progr Ser 578:197-211

van Bemmelen R, Kolbeinsson Y, Ramos R, Gilg O, Alves JA, Smith $\mathrm{M}$ et al (2019) A migratory divide among Red-necked Phalaropes in the Western Palearctic reveals contrasting migration and wintering movement strategies. Front Ecol Evol 7:86
Vansteelant WMG, Kekkonen J, Byholm P (2017) Wind conditions and geography shape the first outbound migration of juvenile honey buzzards and their distribution across sub-Saharan Africa. Proc R Soc B 284:1-9

van Wijk RE, Bauer S, Schaub M (2016) Repeatability of individual migration routes, wintering sites, and timing in a long-distance migrant bird. Ecol Evol 6:8679-8685

Vardanis Y, Nilsson JÅ, Klaassen RHG, Strandberg R, Alerstam T (2016) Consistency in long-distance bird migration: contrasting patterns in time and space for two raptors. Anim Behav 113:177-187

Verhoeven MA, Loonstra AHJ, Hooijmeijer JCEW, Masero JA, Piersma T, Senner NR (2018) Generational shift in spring staging site use by a long-distance migratory bird. Biol Lett 14:20170663

Verhoeven MA, Loonstra AHJ, Senner NR, McBride AD, Both C, Piersma T (2019) Variation from an unknown source: large interindividual differences in migrating black-tailed godwits. Front Ecol Evol 7:31

Warnock N (2010) Stopping vs. staging: the difference between a hop and a jump. J Avian Biol 41:621-626

Webster MS, Marra PP (2005) The importance of understanding migratory connectivity and seasonal interactions. In: Greenberg R, Marra PP (eds) Birds of two worlds: the ecology and evolution of migration. John Hopkins University Press, Baltimore, pp 199-209

Wickham H (2016) ggplot2: elegant graphics for data analysis. Springer, New York

Winger BM, Auteri GG, Pegan TM, Weeks BC (2019) A long winter for the Red Queen: rethinking the evolution of seasonal migration. Biol Rev 94:737-752

Winkler DW, Jørgensen C, Both C, Houston AI, McNamara JM, Levey DJ, Partecke J, Fudickar A, Kacelnik A, Roshier D, Piersma T (2014) Cues, strategies, and outcomes: how migrating vertebrates track environmental change. Mov Ecol 2:2-10

Publisher's Note Springer Nature remains neutral with regard to jurisdictional claims in published maps and institutional affiliations. 